Vera Jakara

Andragoški center

Slovenije

\section{KAKOVOST V PROCESIH \\ PREVERJANJA IN OCENJEVANJA ZNANJA}

M zagotavljanje kakovosti sistema vzgoje in izobraževanja sta tudi preverjanje in ocenjevanje znanja udeležencev izobraževanja. Namen tega kazalca je ugotoviti, koliko izobraževalci razlikujejo preverjanje od ocenjevanja znanja in kaj udeleženci menijo o objektivnosti njihovega ocenjevanja.

V najsplošnejšem pomenu je preverjanje proces zbiranja informacij, ki so namenjene učitelju, pa tudi udeležencem izobraževanja, za

$S$ preverjanjem ugotarljamo, koliko smo se približali ciljem. odločanje o nadaljnjem delu. $\mathrm{S}$ preverjanjem torej sistematično zbiramo podatke o tem, koliko so se udeleženci pod vplivom izobraževalnega programa približali zastavljenim ciljem, z ocenjevanjem pa razumemo merjenje, pri čemer si strokovnjaki (ocenjevalci) pomagajo $\mathrm{z}$ opazovanjem, pisnimi testi, praktičnimi preizkusi ipd. (Ecclestone, 1994). Da bi bili preverjanje in ocenjevanje znanja udeležencev izobraževanja kar se da objektivno, je treba upoštevati nekatera splošna in tudi specifična določila, in sicer pri preverjanju ter ocenjevanju znanja pri otrocih in mladini in še posebej pri odraslih, saj odrasli od nas pričakujejo drugačno ravnanje, že zaradi njihovih življenjskih in delovnih izkušenj. Učitelj, ki poučuje odrasle, se mora zavedati nekaterih značilnosti odra- slih, zato mora biti njegovo delo drugačno. Odrasli so namreč samostojni, materialno, socialno in psihološko neodvisni, iz česar izhaja predstava odraslega o samem sebi in njegova pripravljenost za učenje.

Ocenjevanje je opredeljeno kot dinamičen proces, saj se znanje posameznika lahko zelo hitro dopolnjuje in ga le-ta vnaša v svoj sistem že pridobljenih informacij, izkušenj, znanja. Je proces priznavanja oziroma določanja vrednosti nečesa. Pri ocenjevanju gre najpogosteje za izražanje mnenja strokovnjaka, ki ocenjuje. Da bi bilo to mnenje kar se da objektivno oziroma da bi lahko ugotovili dejansko znanje kandidata in tako naredili korak naprej pri zagotavljanju kakovosti ocenjevanja, je pomembno, da je ves postopek logična celota. Da bi zagotovili večjo kakovost $\mathrm{v}$ procesih ocenjevanja znanja, moramo le-te osmisliti, pri čemer si moramo postaviti naslednja vprašanja:

-Zakaj ocenjujemo?

- Kaj ocenjujemo?

- Kako ocenjujemo?

- Kdaj ocenjujemo?

- Kdo lahko ocenjuje?

\section{ZAKAJ OCENJUJEMO?}

Če si najprej podrobneje ogledamo prvo vprašanje - zakaj ocenjujemo - ugotavljamo, 
da je več razlogov, zakaj preverjamo in ocenjujemo znanje in/ali usposobljenost, med katerimi so gotovo najpomembnejše:

\section{a) Selekcija $s$ preverjanjem in ocenjevanjem}

Selekcija s postopkom preverjanja in ocenjevanja je primerna za določanje ravni znanja/usposobljenosti na določenem področju. S selekcijo ugotovimo posameznikove potrebe in raven, na kateri bi se vključil. To velja toliko bolj za odrasle, saj imajo tudi več delovnih ali drugačnih izkušenj in predznanja, pridobljenega na najrazličnejše načine, ki ga je treba upoštevati pri usmerjanju v nadaljnje učenje ali kariero.

\section{b) Motivacija kandidatov}

Namen ocenjevanja v prejšnji postavki služi bolj organizatorjem kot kandidatom, tu pa je ravno nasprotno. $\mathrm{V}$ tem primeru uporabljamo preverjanje in ocenjevanje zaradi kandidatov, cilj je izobraževalno obarvan in služi predvsem njihovim potrebam. Različne postopke in oblike preverjanja izvajamo, da bi kandidati ugotovili, kaj so dosegli (zunanja motivacija), in da bi jih spodbudili k učenju (notranja motivacija).

\section{c) Povratne informacije kandidatom}

Povratne informacije kandidatu o njegovem delu so izredno pomembne za njegovo učenje in nadaljnji uspeh pri delu. Ta cilj je eden od pomembnejših pri preverjanju. Najpomembnejše je, da damo kandidatu informacije o tem, kaj je napravil dobro ter kaj ne in kako bi se moral zadeve lotiti, da bi jo opravil bolje, kaj bi se moral naučiti in $\mathrm{v}$ čem bi se moral izuriti. Le $\mathrm{v}$ tem primeru so povratne informacije smiselne in zares pomembne pri nadaljnjem učenju ter omogočajo premik h kakovostnejšemu procesu preverjanja in ocenjevanja znanja, le tako lahko namreč govorimo, da učitelj kandidatu $\mathrm{z}$ dajanjem povratnih informacij pomaga pri učenju.

\section{č) Povratne informacije učitelju}

Tako kot da kandidatu ocenjevanje povratne informacije o tem, kako dobro se je določene snovi ali spretnosti naučil, pomaga tudi učitelju pri ugotavljanju, kako dobro je določeno snov predstavil oziroma kako dobro je poučeval, predaval, vodil ali izvajal določeno izobraževalno obliko. $Z$ rezultati ocenjevanja ugotavlja, katere zahtevnejše dele $\mathrm{v}$ snovi je pomanjkljivo predstavil, kje razlaga ni bila dovolj jasna, katere spretnosti je s kandidati premalo vadil ali pa jim ni zagotovil dovolj možnosti za praktično delo. $\mathrm{V}$ tem primeru ocenjevanje delno prispeva informacije za evalvacijo (vrednotenje) določenega programa. Rezultate lahko uporabi za spremembe $\mathrm{v}$ načinu dela pri naslednji skupini.

\section{PREDMET OCENIEVANJA}

Ko si postavimo vprašanje, kaj ocenjujemo, moramo pomisliti na več različnih možnosti, ki se nam pri tem ponujajo. Hkrati z znanjem lahko preverjamo na primer spretnost izražanja, razumevanje snovi, komuniciranje ali druge spretnosti, na primer ročne, ki omogočajo večjo hitrost pri opravljanju dela in s tem povečujejo učinkovitost. Preverjamo lahko tudi vedenje, stališča in vrednote posameznega kandidata, sposobnost reprodukcije in iznajdljivost.

Nekateri učitelji raje ocenjujejo v luči vtisov, ki jih kandidat napravi na njih po preverjanju,

V procesih ocenjevanja znanja se stremi k ěim večji objektivnosti oziroma k ugotavljanju dejanskega znanja kandidata. Uresničitev navedenih ciljev seveda pripomore $\mathrm{k}$ zagotavljanju kakovosti v postopkih ocenjevanja znanja in tudi v celotnem vzgojno-izobraževalnem procesu. Da bi to dosegli, je pomembno predvsem to, da pri postopkih ocenjevanja znanja ne gre le za poznavanje golih vsebin področja, za katerega preverjamo usposobljenost, za ocenjevanje dosežkov $v$ znanju oziroma usposobljenosti, temveč lahko s preverjanjem in ocenjevanjem ugotavljamo tudi dodatne sposobnosti kandidatov. 
a se ne odločajo za analitičen pristop k obravnavanja nalog, projektov ali izdelkov. $\mathrm{V}$ tem primeru učitelj izlušči vse, kar je $v$ nalogi, projektu ipd. dobrega, raje ocenjuje pravzaprav različne postavke, ki jih je kandidat izkazal $\mathrm{v}$ postopku preverjanja naloge, izdelka ipd., kot da bi ocenjeval tiste, za katere bi se vnaprej odločil, da jih bo ocenjeval. Nekateri se bolj ogrevajo za prvi primer in svetujejo, naj pri kandidatu vedno ocenjujemo tisto, kar »priplava na površje «, torej brez vnaprej določenih postavk, ki jih želimo preverjati. Res je namreč, da se lahko zgodi, če učitelj preverja le vnaprej določene postavke, da spregleda to, česar se je kandidat naučil poleg ti-

Z vidika kakovosti
je dobro, da
ocenjujemo po
vnaprej določenih
postavkah in
hkrati ocenimo
tudi tisto, kar je
"nepredvidljivo«.

stega, kar je bilo načrtovano.

Katero možnost izberemo, je odvisno od področja, ki ga ocenjujemo. Čeprav ocenjujemo znanja, ki jih je kandidat pridobil pri določeni eksaktni vedi (na primer matematiki), se lahko kljub vnaprej načrtovanim postavkam, preverjanja odločimo, da bomo upoštevali in ocenili alternativno pot, po kateri je kandidat prišel do pravilnega rezultata $\mathrm{v}$ določeni nalogi. Ko izbiramo obliko preverjanja, deloma že določamo tudi, kaj bomo preverjali. $\mathrm{Na}$ primer, če bomo izbrali esej, ne bomo ocenjevali ustne komunikacije, ker to ni mogoče, temveč poleg vsebine še pisne veščine ali kaj drugega. Zato je morda $\mathrm{z}$ vidika kakovosti procesa ocenjevanja najbolje, da kombiniramo oba načina. Okvirno se odločimo, kaj želimo preveriti, izberemo temu primerne oblike ali metode in smo hkrati sprejemljivi tudi za nepredvidena znanja ali veščine, ki jih kandidat pokaže $\mathrm{v}$ postopku preverjanja.

Če se osredotočimo na vnaprej določene postavke, ki jih želimo preveriti, in smo hkrati sprejemljivi, bomo lahko preverjali številne dodatne postavke, ki bodo, med preverjanjem kandidata nepričakovano »priplavale na po- vršje«. Te dodatne postavke so lahko zelo različne glede na metode preverjanja, ki smo jih uporabili, in jih je dobro zapisati, čeprav niso bile za določen program predvidene kot pridobljeno znanje. Če se na primer izkaže, da je kandidat zelo dober v ustnem sporazumevanju, mu to štejemo v dobro, čeprav za program ta spretnost ni pomembna. Vedno imamo možnost, da opisno ocenimo takšne dodatne postavke. Takšen pristop omogoča pomembne informacije o posamezniku, za delodajalce in osebje v izobraževalnih ustanovah. Pri ocenjevalni vnemi ne smemo pretiravati in kandidatov dosje obremeniti z neuporabnim balastom.

\section{NAČIN OCENJEVANJA}

Za proces ocenjevanja znanja menimo, da je kakovosten, kadar le-ta doseže namen. Da bi ocenjevalci namen ocenjevanja tudi dosegli, je priporočljiva uporaba različnih oblik in metod ocenjevanja. Tako je ocenjevanje lahko formalno ali neformalno, formativno ali sumativno, enkratno ali večkratno, ocenjujemo lahko proces ali produkt ipd. V novejšem času ustvarjajo strokovnjaki na tem področju nove in nove metode, ki jim omogočajo, da čim več izvedo o svojih kandidatih. Učiteljem, ki po-

Pri uporabi najrazličnejših metod ocenjevanja znanja je potrebna tudi določena stopnja previdnosti, saj se pri iskanju podatkov o posamezniku pogosto pretirava. Preverjanje se je $v$ zadnjih letih zelo razvi10. V primerjavi s tradicionalnim, močno zakoličenim preverjanjem, pri katerem so z enakimi oblikami in metodami preverjali najrazličnejšsa znanja in spretnosti (največkrat vprašanja in odgovori), rezultati pa pogosto niso dali realne slike o posamezniku, se ob razcvetu novih pristopov $\mathrm{k}$ preverjanju kaže težnja po pretiravanju v zbiranju podatkov o posamezniku. 
stajajo pravi »detektivi« pri spoznavanju udeležencev, ne bi niti na pamet prišlo, da bi s takimi metodami ocenjevali njihove najbližje ali prijatelje. Pogosto želimo izbrskati veliko več podatkov, kot jih navadno potrebujemo. Zato moramo biti pri uporabi metod kljub njihovi vabljivosti previdni in moramo dobro premisliti, ali je vsa navlaka, ki jo bomo s takšnim preverjanjem pridobili, resnično potrebna in tudi čemu bo služila.

\section{ČAS OCENJEVANJA}

V praksi so se najpogosteje pojavljali primeri preverjanja in ocenjevanja znanja ter sposobnosti udeležencev izobraževanja ob koncu »etap« oziroma preverjanje in ocenjevanje na koncu izobraževanja. Takšno ocenjevanje pomeni v praksi zaključni izpit na koncu programa. Namen takšnega preverjanja in ocenjevanja je ugotoviti, koliko je kandidat obravnavano snov osvojil, ugotoviti pripravljenost udeleženca za samostojno delovanje, za konec programa ipd. Poglavitni namen je torej obvestiti udeleženca izobraževanja o njegovih rezultatih, ne pa mu dati le povratne informacije, ki mu bo v pomoč pri njegovem nadaljnjem učenju.

$S$ preverjanjem in ocenjevanjem na koncu izobraževanja se najpogosteje želi ugotoviti, ali je določen izobraževalni program udeležencem koristil, ali so udeleženci po končanem programu usposobljeni ipd. Ocenjevanje lahko vodi k pridobitvi potrdila (certifikata), poleg tega pa je lahko izhodišče za ugotavljanje dosežkov in postavljanje novih izobraževalnih ciljev. Izvajajo ga lahko predavatelji (izvajalci izobraževanja) oziroma strokovnjaki, usposobljeni za preverjanje in ocenjevanje, lahko pa tudi tim strokovnjakov oziroma mreža institucij, ki med seboj sodelujejo.

$\mathrm{V}$ zadnjem času se, v povezavi z zagotavljanjem kakovosti v vzgojno-izobraževalnem procesu in $\mathrm{s}$ tem tudi $\mathrm{v}$ procesih ocenjevanja znanja, vse bolj poudarja premik od tradicionalnega ocenjevanja znanja k novim vlogam, ki naj bi jih le-to prevzelo. Tako naj bi prešli med drugim tudi od končnega preverjanja znanja (ki je postalo predmet zunanjega preverjanja in ocenjevanja) $\mathrm{k}$ sprotnemu preverjanju in ocenjevanju.

Sprotno preverjanje in ocenjevanje lahko pomenita intervencijo na začetku učenja nove vsebine (poudarek na nujnih in pomembnih sestavinah predhodno pridobljenega znanja), intervencijo med samim procesom izobraževanja (usmerjanje kognitivnih in emocionalnih procesov), lahko pa se pojavita tudi na koncu zaokroženih celot, ko prevzameta prej opisane značilnosti.

Predavatelji in udeleženci lahko s sprotnim preverjanjem in ocenjevanjem izrabijo možnosti za učenje, ki se pojavijo med samim izobraževanjem. Pri tem je pomembno predvsem, da udeležencem damo podatke o njihovem znanju, in sicer o tem, ali in $v$ čem je to Sprotno preverjanje in ocenjevanje pomaga udeležencem izobraževanja pri izboljšanju končnih rezultatov. ustrezno, pravilno, zadovoljivo, po drugi strani pa opozorimo na pomanjkljivosti in nepravilnosti. Takšne informacije omogočajo natančno informiranje udeležencev izobraževanja o njihovem znanju in vrzelih v njem. Tako lahko posamezniki nenehno napredujejo $\mathrm{k}$ boljšemu oziroma pravilnemu znanju. Poleg tega zagotavljata sprotno preverjanje in ocenjevanje podatke o tem, ali udeleženci pri izobraževanju napredujejo ali nazadujejo. Pri tem je pomembno, da posameznike ne primerjamo z drugimi, temveč je treba njihove trenutne rezultate primerjati s predhodnimi.

$S$ sprotnim preverjanjem in ocenjevanjem znanja lahko dosežemo premike, ki so pomembni z vidika zagotavljanja kakovosti:

- premik od pretežno sumativnega $\mathrm{k}$ formativnemu in diagnostičnemu preverjanju ter ocenjevanju; 




- premik od ocenjevanja kognitivnih prvin k ocenjevanju praktičnih spretnosti in drugih sestavin;

- premik od ocenjevanja produktov k ocenjevanju procesov in produktov;

- premik od pretežno pisnega preverjanja in ocenjevanja k pestrosti in kombinaciji oblik preverjanja;

- premik od ocenjevanja na koncu izobraževanja k sprotnemu spremljanju dosežkov;

- premik od poudarjanja napak ter pomanjkljivosti k realnemu vrednotenju dosežkov in pomanjkljivosti (Preverjanje in ocenjevanje znanja, 1992).

\section{KDO LAHKO OCENJUJE?}

V zvezi s preverjanjem in ocenjevanjem zna- ljevega dela, saj nalaga postavljena ocena predavatelju veliko moralno odgovornost in je ena največjih psihičnih obremenitev tega poklica.

$\mathrm{V}$ praksi velja mnenje, da je ocena subjektiven zaznamek. Izraža namreč predavateljevo razpoloženje, njegove osebnostne poteze in njegov odnos do udeležencev izobraževanja, ki temelji predvsem na čustvenem nasprotju med simpatijo in antipatijo. Zato se pojavljajo številni predlogi in ukrepi, ki naj bi pripeljali do večje objektivnosti oziroma ki naj bi omilili razhajanja med posameznimi predavatelji ter tako omogočili premik $\mathrm{k}$ večji kakovosti postopka ocenjevanja.

$\mathrm{V}$ praksi najpogosteje potekata preverjanje in ocenjevanje znanja brez vključitve udeležencev izobraževanja. Predavatelji udeležencem znanje posredujejo in osvojeno znanje tudi preverjajo ter ocenjujejo. Pri tem si mnenje o 
udeležencih in njihovem znanju oblikujejo na podlagi predpostavke, da udeležence poznajo ter da poznajo tudi njihovo mišljenje ter čustvovanje. Redko se zgodi, da za mnenje med preverjanjem in ocenjevanjem povprašamo tudi udeležence.

Pri preverjanju in ocenjevanju znanja ter sposobnosti udeležencev izobraževanja ni nujno, da le-to izvaja izključno predavatelj oziroma ocenjevalec. V zadnjem času se vse bolj uveljavlja ideja o preverjanju in ocenjevanju z vidika tako imenovanega študijskega kolega. Udeleženci izobraževanja lahko namreč rezultate svojega dela primerjajo z rezultati svojih kolegov. Pomembno je, da predavatelj poskrbi za rešitve in ustrezen točkovni sistem, kolegi, ki izdelke preverjajo in ocenjujejo, pa svoje ugotovitve tudi pisno utemeljijo. Pisne pripombe lahko udeleženci komentirajo naprej, tudi v diskusiji s predavateljem. Pri takšnem preverjanju in ocenjevanju se pojavi problem, kadar gre za preverjanje in ocenjevanje pisnih izdelkov z esejskim tipom odgovorov, saj sta vprašljivi predvsem veljavnost ter zanesljivost preverjanja in ocenjevanja. Predavatelj mora $\mathrm{v}$ takem primeru izdelati čimbolj natančen seznam splošnih in posebnih meril ter točkovne sheme, ki so temelj preverjanja in ocenjevanja.

$\mathrm{Na}$ področju zagotavljanja kakovosti $\mathrm{v}$ postopkih preverjanja in ocenjevanja je treba storiti predvsem premik $\mathrm{k}$ večji in resnični vključenosti udeležencev izobraževanja $v$ proces preverjanja znanja (poudarek na samopreverjanju) in tudi $v$ proces opisovanja in ocenjevanja lastnih dosežkov (samoocenjevanje). Udeleženci izobraževanja se tako spremenijo iz pasivnih $\mathrm{v}$ aktivne predavateljeve sodelavce, poleg tega pa imajo možnost spremljanja lastnega napredovanja, spoznavanja svojih močnih in šibkih področij ter načrtovanja nadaljnjega učenja. Vključevanje udeležencev izobraževanja v preverjanje in ocenjevanje pozitivno vpliva na njihovo motiva- cijo, daje učenju smisel, povečuje zaupanje udeležencev v lastne sposobnosti in v možnosti za uspeh. Pomembno je torej spoznanje, da so lahko poleg predavateljev, tutorjev, ocenjevalcev, študijskih kolegov tudi udeleženci izobraževanja uspešno ovrednotijo svoje znanje in sposobnosti.

Samoocenjevanje pomaga udeležencem izobraževanja razumeti in izboljšati njihove zmožnosti. Pomembno je, da so merila preverjanja in ocenjevanja jasno zastavljena, da se lahko udeleženci naučijo ocenjevati, kaj so z izobraževanjem dosegli, ne pa truda, ki so ga vložili. Pri tem je pomembno, da so natančno izdelani tudi standardi znanja, ki naj bi jih udeleženci dosegli, pri tem pa je potrebno strinjanje predavatelja in udeležencev.

S samoocenjevanjem se lahko poveča odgovornost udeležencev izobraževanja, tako da so v končni fazi pripravljeni na vseživljenjsko učenje brez nenehne prisile in nadzora.

Večina strokovnjakov poudarja pomen sodelovanja udeležencev izobraževanja na vseh stopnjah preverjanja in ocenjevanja znanja. Soodgovorni naj bi bili za vse etape, torej za načrtovanje, organizacijo, izpeljavo in vrednotenje. Prepričanje, da predavatelj $\mathrm{v}$ takem primeru ni več potreben, je zmotno, saj je predavateljeva vloga še vedno pomembna, zlasti pri strukturiranju učnega okolja, kjer so udeleženci deležni vodenja in podpore pri učenju ter pomoči pri razvijanju spretnosti za samoocenjevanje.

Sodelovanje udeležencev izobraževanja pri preverjanju in ocenjevanju znanja naj bi potekalo takole:

- Pri načrtovanju: preverjanje in ocenjevanje znanja naj bosta napovedana, udeleženci naj imajo torej možnost vplivati na čas preverjanja in ocenjevanja znanja.

- Pri učenju: samoocenjevanje se pojavlja kot sestavni del formativnega ocenjevanja (namenjeno pomoči udeležencem izobraževanja; pridobijo si informacije o tem, kaj so se že naučili). Pojavlja se med samim proce- 
som učenja, in ne le takrat, kadar domnevamo, da je proces že končan; s samoocenjevanjem usmerjamo udeležence izobraževanja $\mathrm{k}$ pravilnemu učenju, poleg tega pa omogoča dobre odnose med predavateljem in udeleženci, obenem pa pripomore $\mathrm{k}$ spodbujanju kakovostnega in avtonomnega učenja. Pri razvijanju sposobnosti samoocenjevanja je pomembno, da ga sprejmejo, podpirajo in izvajajo predvsem predavatelji. Kolikor bodo pri tem »dobri«, toliko bo uspešen tudi sistem samoocenjevanja.

- Pri izpeljavi: pomembno je, da učitelj skupaj z udeleženci izobraževanja izbere tako obliko (ustno, pisno, praktično) preverjanja in ocenjevanja, ki bo udeležencem omogočila, da pokažejo svoje znanje ali spretnosti.

- Pri vrednotenju: udeleženci sami vrednotijo dosežke, od njih se pričakuje refleksija o procesu učenja. Samoocenjevanje udeležencev, ki poteka $\mathrm{v}$ dialogu s predavateljem, le-temu omogoča spoznavanje razmišljanja in razumevanja udeležencev izobraževanja ter spoznavanje njihovih spoznavnih procesov. Pri tem je pomembno, da je tudi predavatelj sposoben refleksije lastnih spoznavnih procesov. ${ }^{1}$

\section{KAKO DO VEČJE OBJEKTIVNOSTI IN NATANČNOSTI V POSTOPKIH PREVERJANJA IN OCENJEVANJA ZNANJA?}

Na podlagi opisanega lahko povzamemo, da morata imeti preverjanje in ocenjevanje znanja udeležencev izobraževanja, ki naj bi bila čimbolj natančna in objektivna in bi tako pripomogla $\mathrm{k}$ povečanju kakovosti izobraževalnega procesa, vnaprej opredeljene:

- standarde znanja,

- merila ocenjevanja in

- metode ocenjevanja.
Pri preverjanju in ocenjevanju znanja, s katerim želimo ugotoviti dejansko znanje kandidata, je treba najprej natančno opredeliti standarde znanja. Pri opredelitvi standardov znanja je treba torej natančno določiti, kaj mora posameznik na koncu izobraževalnega programa znati oziroma kaj mora biti zmožen napraviti. Standardi znanja morajo biti namreč postavljeni jasno. Dobro jih morajo poznati in razumeti vsi, ki v procesu preverjanja in ocenjevanja sodelujejo, torej kandidati, svetovalci, ocenjevalci, mentorji ... Znati pa jih morajo tudi pravilno uporabljati.

Vsak posameznik namreč razume določen pojav na njemu lasten način. Te razlage so lahko izjemno subjektivne, so le del stvarne resnice. Subjektivnosti pri razumevanju določenih pojavov se lahko izognemo $z$ večjim številom ocenjevalcev, pri čemer se objektivnost preverjanja in ocenjevanja ne povečuje le zaradi njihovega večjega števila, temveč predvsem zaradi njihovih različnih zornih kotov, iz katerih preverjajo in ocenjujejo.

Pri ugotavljanju uspešnosti udeležencev izobraževanja je treba tudi določiti, kaj z uspešnostjo sploh razumemo. Mnogi strokovnjaki trdijo, da je mogoče uspešnost različno meriti. Pri tem je treba izbrati ustrezna merila oziroma kriterije, s katerimi lahko to uspešnost določimo.

Merila za doseganje postavljenih ciljev, ki naj bi pripomogli k objektivnemu in kakovostnemu ocenjevanju, morajo biti trdna, dovolj jasno zastavljena, enoznačna in veljavna. To pomeni, da resnično zajemajo bistvo predmeta preverjanja in ocenjevanja. Poleg tega usmerjajo posameznika, ki se uči, na njih temeljijo odločitve o tem, kaj mora posameznik še predelati, občutek, kako hitro $\mathrm{z}$ učenjem napreduje, $\mathrm{k}$ čemur učenje končno tudi vodi. Natančno izdelana merila vplivajo tudi na motivacijo udeležencev izobraževanja. 
Merila preverjanja in ocenjevanja so lahko različno zahtevna, najbolj pa se zaostrijo pri pridobivanju formalne izobrazbe. Učitelji morajo namreč pri tem uspešnost vrednotiti s šolskimi ocenami in spričevali, merila ocenjevanja pa so $\mathrm{v}$ tem primeru jasna in omogočajo primerjanje.

Objektivnost in kakovost preverjanja in ocenjevanja sta odvisni tudi od metod, s katerimi preverjamo in ocenjujemo znanje ter sposobnosti posameznika. Metodo lahko označimo kot pot, po kateri preverjanje in ocenjevanje izvedemo. Čim preprostejša in čim bolj prilagojena je metoda, objektivnejša je ocena.

Med pisano paleto metod, ki jih za preverjanje in ocenjevanja znanja ter sposobnosti lahko uporabimo, se je treba odločiti za tisto ali tiste, ki bodo $\mathrm{v}$ danih okoliščinah najbolje prikazale posameznikovo znanje ali usposobljenost. Pri izbiri je pomembno, da natančno vemo, kaj želimo preverjati in ocenjevati, kaj je za določene okoliščine najpomembnejše in katera metoda bo to najbolje osvetlila. Pogosto je treba pri preverjanju in ocenjevanju znanja in sposobnosti posameznika kombinirati večje število različnih metod, če je to $\mathrm{v}$ korist boljšega uvida v znanje in usposobljenost posameznika.

Tako lahko na primer za preverjanje in ocenjevanje znanja, določenih pravil, sistemov, standardov ipd. uporabljamo teste različnih tipov, projektno ali seminarsko nalogo, metodo pogovora ali intervjuja, pri preverjanju in ocenjevanju sposobnosti posameznika pa uporabljamo metode demonstracije, simulacije ali igre vlog, metodo preverjanja $\mathrm{z}$ računalnikom, metodo opazovanja na delovnem mestu. Pomembno je, da pri preverjanju in ocenjevanju znanja ter sposobnosti uporabljamo metode, ki omogočajo poleg preverjanja in ocenjevanja znanja in sposobnosti tudi preverjanje posameznikove sposobnosti za aktivno rabo naučenega v praksi. Posameznik mora biti namreč sposoben znanja tudi prenašati ne le v običajno delovno okolje, temveč v različna delovna okolja in $\mathrm{v}$ različne okoliščine.

C. Gipps, ${ }^{2}$ britanska strokovnjakinja, poudar$\mathrm{ja}$, da se je treba pri preverjanju in ocenjevanju premakniti od kulture testiranja in spraševanja $\mathrm{h}$ kulturi preverjanja in vrednotenja v različnih oblikah. Značilnosti njenega pristopa:

- Ocenjevanje poteka v manj nadzorovanih okoliščinah, ne išče »objektivnega« rezultata, je spodbujevalno in išče pri posamezniku najboljši možni (in ne značilni) rezultat, in sicer v sproščenih razmerah (ne v stresnem položaju). Ocenjevanje mora potekati v običajnih okoliščinah, ki ne povzročajo blokade.

- Uporabljajo se različni postopki in široka paleta dejavnosti, ki omogočajo v danih okoliščinah in za dane Za večjo kakovost je potreben premik od kulture testiranja do kulture vrednotenja. vsebine dobiti najboljši možni rezultat. Razlikujejo se lahko tudi načini odgovarjanja (pisni, ustni, praktični).

- Dosežki so spremenljivi, zato skušamo z ocenjevanjem vplivati na udeležence, da bi jih izboljšali; posamezniku pomagajo, omogočajo, ga spodbujajo, da se razvija in napreduje, so $\mathrm{v}$ podporo procesu učenja (pridobivanju znanja).

- Med ocenjevalcem in udeležencem je omogočena interakcija (pojasnjevanje $\mathrm{z}$ obeh strani).

- Dosežki se opisujejo, poudarek je na kakovosti individualnega rezultata, opis z vidika kakovosti omogoča razumevanje dosežkov $\mathrm{v}$ razmerju do posameznikovih zmožnosti, njegovih prejšnjih dosežkov in do konteksta.

- Pri ocenjevanju ne gre za primerjavo med posamezniki. Primerjava namreč slabo vpliva na samopodobo udeležencev izobraževanja, vpliva na težnjo po izogibanju so- 
delovanju v dejavnosti, kjer uspeh ni zagotovljen, slabo vpliva na razvoj interesov in na storilnostno motivacijo (lotevanje izzivalnih nalog), povzroča tudi uporabo slabših ali manj učinkovitih miselnih strategij.

Premik k »sodobnejšim« načinom preverjanja in ocenjevanja pripomore predvsem $\mathrm{k}$ izboljšanju veljavnosti preverjanja in ocenjevanja samega, poleg tega pa $\mathrm{k}$ izboljšanju poučevanja. Predavatelji oziroma ocenjevalci so pozorni na to, kako se udeleženci učijo, naučijo se opazovati in razčlenjevati proces učenja, spretnosti in sposobnosti udeležencev izobraževanja, pri preverjanju in ocenjevanju niso usmerjeni le $\mathrm{k}$ preučevanju rezultatov učenja, temveč predvsem $\mathrm{k}$ procesu učenja.

\section{SKLEPNE MISLI}

Zagotavljanje kakovosti v procesih preverjanja in ocenjevanja znanja je eden izmed pomembnih kazalcev za ugotavljanje in zagotavljanje kakovosti celotnega vzgojno-izobraževalnega procesa. Pri tem je treba poudariti, da osnovni namen postopkov preverjanja in ocenjevanja znanja ni preveriti, koliko in kako uspešno so si kandidati zapomnili posredovane informacije. Objektivno ter kakovostno preverjanje in ocenjevanje omogočata, poleg ugotavljanja dejanskega znanja, da bo posameznik znal osvojeno znanje tudi uporabiti, ne le v običajnih, temveč tudi v nepredvidljivih, nevsakdanjih življenjskih in delovnih situacijah. Ti napotki so lahko eden izmed načrtov, kako lahko to tudi dosežemo.

\section{LITERATURA}

Bergant, M. (1992). Preverjanje in ocenjevanje znanja, Ljubljana: Zavod RS za šolstvo in šport.

Ecclestone, K. (1994). Understanding Assessment, Leicester: National Institute of Adult Continuing Education.

Razdevšek - Pučko, C. (1996): Drugačne oblike preverjanja in ocenjevanja znanja. Sodobna pedagogika, 47, str. 411-419.
Jelenc, N. E., Jakara, V.: Preverjanje in ocenjevanje znanja pri odraslih. Ljubljana: Andragoški center Republike Slovenije (priročnik v delu).

Ugotavljanje in zagotavljanje kakovosti v vzgoji in izobraževanju. Zavod za šolstvo RS, Šola za ravnatelje, Center za poklicno izobraževanje, Ministrstvo za šolstvo in šport.

${ }^{1}$ Razdevšek Pučko, Cveta: Drugačne oblike preverjanja in ocenjevanja znanja, Sodobna pedagogika, letnik 47, st. 9-10, 1996.

${ }^{2}$ Razdevšek Pučko, Cveta: Drugačne oblike preverjanja in ocenjevanja znanja, Sodobna pedagogika, letnik 47, št. 9-10, 1996. 